\title{
PERBEDAAN POLA TIDUR ANTARA KELOMPOK TERLATIH DAN TIDAK TERLATIH
}

\author{
Oleh: \\ Arif Hidayat Suwarna dan Widiyanto \\ Pendidikan kesehatan dan Rekreasi FIK UNY
}

\begin{abstract}
Abstrak
Faktor keterlatihan berpengaruh terhadap pola tidur seseorang. Penelitian ini bertujuan untuk mengetahui perbedaan pola tidur antara kelompok terlatih dan tidak terlatih. Penelitian ini merupakan penelitian ex-post-facto menggunakan metode survei dengan teknik pengambilan data menggunakan angket. Populasi dalam penelitian ini adalah ibu-ibu komplek Tarakanita dan ibu-ibu member senam aerobik di The Sahid Rich Yogyakarta Hotel. Pengambilan sampel menggunakan teknik purposive sampling yaitu responden dari ibu-ibu komplek Tarakanita dipilih yang tidak aktif berolahraga, sedangkan responden dari ibu-ibu member senam aerobik di The Sahid Rich Yogyakarta Hotel dipilih yang rutin senam setidaknya tiga kali dalam seminggu. Total sampel sebanyak 33 orang. Teknik analisis data dalam penelitian ini menggunakan uji-t dengan syarat uji-t berupa uji normalitas dan uji homogenitas.

Hasil penelitian menunjukkan adanya perbedaan yang signifikan antara pola tidur kelompok terlatih yaitu ibu-ibu member senam aerobik di The Sahid Rich Yogyakarta Hotel dan pola tidur kelompok tidak terlatih yaitu ibu-ibu komplek Tarakanita dengan hasil bahwa pola tidur ibu-ibu member senam aerobik di The Sahid Rich Yogyakarta Hotel lebih baik dari ibu-ibu komplek Tarakanita. Hasil tersebut ditunjukkan dengan $\mathrm{t}$ hitung sebesar 3,468 dan $\mathrm{p}=0,002$, mean yang diperoleh ibu-ibu komplek Tarakanita sebesar 94,00, sedangkan mean yang lebih tinggi dimiliki oleh ibu-ibu member senam aerobik di The Sahid Rich Yogyakarta Hotel sebesar $=104,75$. Berdasarkan hasil tersebut dapat dikatakan bahwa terdapat perbedaan pola tidur antara kelompok terlatih dan kelompok tidak terlatih.
\end{abstract}

Kata kunci: pola tidur dan tingkat keterlatihan

Manusia adalah makhluk sosial yang tidak lepas dari kesibukan dalam menjalani kesehariannya. Berbagai aktivitas dilakukan baik dari golongan sosial bawah, menengah, ataupun golongan sosial tingkat atas. Keseharian yang dijalani terkadang membuat banyak orang melalaikan kondisi fisiknya. Padahal dengan kondisi fisik yang prima dan bugar dapat mengangkat serta menunjang kehidupan sosial orang itu sendiri. Pola hidup pegawai kantoran misalnya. Pekerjaan yang banyak dihabiskan di dalam ruangan dengan sedikit aktivitas gerak yang terjadi tentu menjadi rahasia umum dan menjadi kendala bagi yang tidak bisa menyempatkan untuk berolahraga secara teratur. Suharjana (2013: iii) mengatakan bahwa olahraga yang teratur adalah olahraga yang dilakukan secara kontinyu satu minggu tiga kali, dengan waktu latihan antara 20-60 menit untuk setiap kali olahraga. Olahraga yang teratur 
dapat bermanfaat untuk menjaga kebugaran tubuh manusia, kita ketahui bahwa kebugaraan itu memiliki definisi sebagai kemampuan fisik yang optimal untuk melakukan aktivitas sehari-hari tanpa kelelahan yang berlebih dan masih sanggup untuk melanjutkan aktivitas ringan lainnya. Banyak cara yang dapat dilakukan sebagai usaha untuk menjaga kondisi fisik tetap bugar. Berbagai variasi latihan seperti berenang, jogging, dan senam aerobik adalah beberapa contohnya. Tubuh manusia didesain untuk selalu bergerak sehingga sangat dianjurkan untuk rajin olahraga. Ketika otot dan rangka tubuh bergerak, denyut jantung akan meningkat sehingga darah beserta oksigen dan nutrisi yang dibawanya akan terdistribusi dengan baik. Mekanisme ini tidak terjadi jika tubuh tidak olahraga.

Terganggunya distribusi oksigen paling berdampak pada otot, yang menyebabkan rasa pegal-pegal di seluruh tubuh. Otot akan terasa kaku-kaku saat kekurangan oksigen, yang memang berfungsi menjaga fleksibilitas atau kelenturan otot. Selain itu, kekurangan oksigen juga menyebabkan kerja otak tidak maksimal sehingga mudah pusing dan susah menjaga konsentrasi. Otak yang ukurannya hanya $2 \%$ dari total massa tubuh dikenal sangat rakus, sebab konsumsi oksigennya mencapai $20 \%$ kebutuhan total tubuh. Pengaruhnya terhadap sistem saraf, tidak bergerak seharian saja akan menyebabkan bagian-bagian tertentu dari tubuh mengalami tekanan yang konstan sepanjang hari. Akibatnya terjadi gangguan saraf di bagian tersebut dan memicu berbagai keluhan ringan seperti nyeri dan kesemutan. Tidak bergerak dan berolahraga juga akan berdampak pada distribusi cairan limfe. Tidak seperti darah yang memiliki jantung sebagai pemompanya, limfe sangat tergantung pada gerakan otot untuk bisa didistribusikan ke berbagai jaringan tubuh. Padahal cairan limfe yang diproduksi oleh suatu kelenjar tanpa saluran (ductless) ini merupakan bagian dari sistem imun atau kekebalan tubuh. Dampaknya tentu saja kekebalan tubuh akan menurun, sehingga mudah terserang penyakit terutama jika sedang musim flu.

Sebuah penelitian yang dilakukan oleh University of Hong Kong pernah mengungkap dampak jangka panjang dari tidak pernah berolahraga tidak kalah bahayanya dengan merokok. Penelitian yang dilakukan tahun 2004 itu menyebut, $20 \%$ penyebab kematian orang dewasa berusia 35 tahun ke atas adalah kurang olahraga. Kurang olahraga juga menyebabkan wajah seseorang cenderung tampak lesu, letih sepanjang hari dan kurang bergairah. Karena kurang olahraga juga memicu gangguan tidur, pada pagi hari orang itu pasti sering mengeluh masih mengantuk karena semalam tidurnya tidak nyenyak (Uyung Pramudiarja, 2015). Banyak yang belum menyadari bahwa dengan tubuh yang sehat orang dapat memiliki pola tidur yang baik. Salah satu manfaat dari tubuh yang sehat dengan berolahraga teratur adalah dapat memiliki pola tidur yang baik, sehingga mampu mengurangi 
berbagai masalah tidur dan dapat tidur dengan nyenyak dan pulas. Tracey Kelly (2005: 6) mengatakan bahwa olahraga secara teratur penting untuk menciptakan tidur yang berkualitas. Tanpa olahraga, fisik tidak akan cukup lelah untuk beristirahat dengan baik di malam hari.

Di sini penulis ingin mengetahui perbedaan pola tidur antara kelompok terlatih dan tidak terlatih. Berdasarkan hasil observasi dan wawancara kepada ibu-ibu di daerah Santren, Catur Tunggal, kabupaten Sleman, tepatnya di komplek Tarakanita. Diketahui terdapat keluhan gangguan tidur yang dialami ibu-ibu di daerah tersebut. Dalam hal ini, penulis menggolongkan ibu-ibu komplek Tarakanita untuk menjadi responden kelompok yang tidak terlatih, sedangkan kelompok yang terlatih penulis memilih member senam aerobik di The Sahid Rich Yogyakarta Hotel dengan pertimbangan kegiatan senam aerobik yang rutin dilakukan enam kali dalam seminggu memenuhi kriteria olahraga teratur.

\section{KAJIAN PUSTAKA}

\section{Pola Tidur}

Menurut Potter (Trusna Nurmansyah, 2009) tidur adalah suatu keadaan yang berulangulang disertai perubahan status kesadaran yang terjadi selama periode tertentu. Beberapa ahli berpendapat bahwa tidur diyakini dapat memulihkan tenaga karena tidur memberikan waktu untuk perbaikan dan penyembuhan sistem tubuh untuk periode keterjagaan berikutnya. Tidur adalah sebuah fungsi biologis yang sangat menarik. Tidak kurang sepertiga dari hidup dihabiskan untuk tidur. Sudah menjadi hal yang lumrah ketika manusia tidur dengan nyenyak maka di pagi harinya saat terbangun tubuh merasa segar dan dapat bekerja dengan lebih baik dibandingkan dengan orang yang kurang istirahat.

Berdasarkan KBBI kata "pola" diartikan sebagai sistem atau cara kerja. Maka dari itu pola tidur dapat diartikan sebagai sistem atau susunan perubahan status kesadaran yang terjadi selama periode tertentu sebagai bentuk mekanisme tubuh untuk beristirahat. Menurut Prayitno (2002: 4) pola tidur adalah model, bentuk atau corak tidur dalam jangka waktu yang relatif menetap dan meliputi (1) jadwal jatuh (masuk) tidur dan bangun, (2) irama tidur, (3) frekuensi tidur dalam sehari, (4) mempertahankan kondisi tidur, dan (5) kepuasan tidur. Mencari sebab timbulnya gangguan tidur adalah langkah awal dalam mengatasi problematika tidur. Insomnia adalah salah satu gangguan tidur yang umum dialami manusia. Insomnia adalah kesukaran dan kecemasan karena tidak dapat segera tertidur sementara keinginan untuk tidur itu sendiri telah ada (Moses Wong, 2005). Potter (Trusna Nurmansyah, 2009) mengatakan insomnia adalah ketidakmampuan untuk mencukupi kebutuhan tidur baik 
kualitas maupun kuantitas. Jenis insomnia ada tiga macam yaitu insomnia inisial atau tidak dapat memulai tidur, insomnia intermitten atau tidak dapat mempertahankan tidur atau sering terjaga dan insomnia terminal atau bangun secara dini dan tidak tidak dapat tidur kembali.

Prawitasari (Setiyo Purwanto, 2008) menjelaskan bahwa pada sistem saraf manusia terdapat sistem saraf pusat dan sistem saraf otonom. Fungsi sistem saraf pusat adalah mengendalikan gerakan-gerakan yang dikehendaki, misalnya gerakan tangan, kaki, jari-jari dan sebagainya. Sistem saraf otonom berfungsi mengendalikan gerakan-gerakan yang otomatis, misalnya fungsi digestif, proses kardiovaskuler, gairah seksual dan sebagainya. Sistem saraf otonom terdiri dari sistem saraf simpatis dan sistem saraf parasimpatis yang kerjanya saling berlawanan. Sistem saraf simpatis bekerja meningkatkan rangsangan atau memacu organ-organ tubuh, memacu meningkatnya detak jantung dan pernafasan, menurunkan temperatur kulit dan daya hantar kulit, dan juga menghambat proses digestif dan seksual. Sistem saraf parasimpatis menstimulasi turunnya semua fungsi yang dinaikkan oleh sistem saraf simpatis, dan menstimulasi naiknya semua fungsi yang diturunkan oleh sistem saraf simpatis. Selama sistem-sistem tersebut berfungsi normal dalam keseimbangan, bertambahnya aktivitas sistem yang satu akan menaikkan efek sistem yang lain. Pada waktu individu mengalami ketegangan atau kecemasan yang bekerja adalah sistem saraf simpatis, sedangkan pada waktu relaksasi yang bekerja adalah sistem saraf parasimpatis, dengan demikian apabila sistem-sistem saraf tersebut tidak berjalan normal akan menimbulkan efek negatif seperti kecemasan yang dapat mengganggu pola tidur.

Kebutuhan tidur pada malam hari bukan saja menjauhkan manusia dari lingkungan yang berbahaya, tetapi juga memenuhi kebutuhan manusia untuk istirahat dan menyimpan energi. Tidur merupakan fungsi biologis pembawaan lahir, sebagaimana terbukti dari telaah di dalam laboratorium. Sekali pun sebuah ruangan diterangi terus-menerus tanpa diketahui apakah siang dan malam, manusia akan tetap membutuhkan tidur dalam siklus waktu 24 jam. Seiring dengan bertambahnya usia, kebutuhan tidur seseorang relatif semakin menurun. Menurut sebuah penelitian, orang dewasa sehat butuh tidur lebih sedikit dibanding orang muda. Sekalipun pada malam harinya kurang tidur, mereka menghadapi kemungkinan lebih kecil untuk merasa lelah siang hari (travel.kompas.com). Tidur yang ideal adalah tidur dengan kuantitas dan kualitas yang baik yang akan menimbulkan efek segar saat terjaga di pagi hari dengan durasi tidur sesuai kebutuhan sesuai jenjang usia. Berikut rekomendasi durasi tidur yang spesifik bagi tiap jenjang usia yang dikutip dari health.kompas.com:

a. Bayi baru lahir (0-3 bulan): durasi tidur diperkecil menjadi 14-17 jam per hari. Sebelumnya 12-18 jam. 
b. Bayi usia 4-11 bulan: durasi tidur ditambah menjadi 12-15 jam. Sebelumnya 14-15 jam.

c. Balita (1-2 tahun) : durasi tidur ditambah menjadi 11-14 jam sebelumnya 12-14 jam.

d. Balita 3-5 tahun: durasi tidur dipersempit menjadi 11-13 jam. Sebelumnya berjumlah 1113 jam.

e. Anak-anak usia 6-13 tahun: durasi tidur menjadi 9-11 jam. Sebelumnya 10-11 jam.

f. Remaja usia 14-17 tahun: durasi tidur mereka ditambah satu jam sehingga menjadi 8-10 jam per hari. Sebelumnya hanya 8,5-9,5 jam.

g. Orang menuju dewasa (18-25 tahun): kategori ini merupakan kategori baru. Durasi tidurnya 7-9 jam per harinya.

h. Orang dewasa (26-64 tahun): durasi tidur tetap, yakni 7-9 jam.

i. Orang lanjut usia (65 tahun ke atas): kategori baru. Durasi tidur 7-8 jam per hari. konsolidasi ingatan (Beny Atmadja, 2002).

Tidur dapat berfungsi dalam pemeliharaan fungsi jantung terlihat pada denyut turun 10 hingga 20 kali setiap menit. Selain itu, selama tidur tubuh melepaskan hormon pertumbuhan untuk memperbaiki dan memperbaharui sel epitel dan khusus seperti sel otak. Otak akan menyaring informasi yang telah terekam selama sehari dan otak mendapatkan asupan oksigen serta aliran darah serebral dengan optimal sehingga selama tidur terjadi penyimpanan memori dan pemulihan kognitif. Fungsi lain yang dirsakan ketika individu tidur adalah reaksi otot sehingga laju metabolik basal akan menurun. Hal tersebut dapat membuat tubuh menyimpan lebih banyak energi saat tidur. Bila individu kehilangan tidur selama waktu tertentu dapat menyebebkan perubahan fungsi tubuh, baik kemampuan motorik, memori dan keseimbangan. Jadi, tidur dapat membantu perkembangan perilaku individu karena individu yang mengalami masalah pada tahap REM akan merasa bingung dan curiga (Agnes Wahyu, 2014). Secara umum faktor-faktor kesulitan tidur menurut Rafknowledge dalam Agnes Wahyu (2014):

a. Stres atau kecemasan. Saat didera kegelisahan yang dalam, biasanya karena memikirkan permasalahanyang sedang dihadapi.

b. Depresi. Selain menyebabkan insomnia, depresi juga menimbulkan keinginan untuk tidur terus sepanjang waktu karena ingin melepaskan diri dan masalah yang dihadapi.

c. Kelainan-kelainan kronis. diabetes, sakit ginjal, artritis, atau penyakit yang mendadak seringkali menyebabkan kesulitan tidur.

d. Efek samping pengobatan pengobatan untuk suatu penyakit juga dapat menjadi penyebab insomnia. 
e. Pola makan yang buruk, mengkonsumsi makanan berat saat sebelum tidur bisa menyulitkan untuk tidur.

f. Kafein, nikotin, dan alkohol.

g. Kurang berolahraga. Juga bisa menjadi faktor sulit tidur yang signifikan.

Penyebab lainnya yang bisa berkaitan dengan kondisi-kondisi spesifik. Secara spesifik kesulitan tidur juga dipengaruhi oleh kondisi-kondisi: (a) Usia lanjut (insomnia lebih sering terjadi pada orang yang berusia di atas 60 tahun). (b) Wanita hamil. (c). Riwayat depresi. Menurut Aman (Trusna Nurmansyah, 2009) ada beberapa hal yang bisa dilakukan untuk mencapai pola tidur yang sehat, yaitu:

a. Disiplin waktu, sebaiknya tentukanlah kapan kita harus tidur dan kapan harus bangun. Para ahli tidur menyakini ritme dan jadwal tidur yang tetap serta teratur akan memberikan kontribusi positif terhadap tidur yang sehat.

b. Lakukan olahraga secata teratur, olahraga ini diyakini sebagai obat yang ampuh untuk menetralisir ketegangan fisik dan pikiran. Waktu yang ideal adalah pagi hari atau sore hari.

c. Perhatikan kondisi ruang tidur. Suasana yang nyaman di dalam kamar akan sangat menentukan kualitas tidur maka jagalah suasana di dalam kamar agar selalu nyaman.

d. Usahakan tidak makan sebelum tidur sebab makan pada saat larut malam atau menjelang tidur, bisa merangsang pencernaan dan membuat kita sulit untuk memejamkan mata.

\section{Latihan Olahraga}

Latihan dapat didefinisikan sebagai suatu proses sistematis yang dilakukan dalam jangka waktu panjang, berulang-ulang, progresif, dan mempunyai tujuan untuk meningkatkan kemampuan dan penampilan fisik. Suharjana (2013: 38) mengatakan bahwa latihan untuk kebugaran jasmani berarti suatu proses sistematis untuk mengembangkan dan mempertahankan unsur-unsur kebugaran jasmani yang dilakukan dalam waktu lama, ditingkatkan secara progresif, beban bersifat individual dan dilakukan secara terus menerus. Latihan dapat berjalan sesuai tujuan apabila sesuai dengan kaidah-kaidah latihan yang benar. Konsep FITT (Frequency, Intensity, Time, dan Type) merupakan konsep latihan yang telah banyak disepakati oleh para pakar olahraga. Olahraga yang sistematik dan dalam waktu yang lama, ditingkatkan secara progresif dan individual yang mengarah pada ciri-ciri fungsional psikologi dan fisiologi manusia untuk mencapai sasaran latihan yang dituju merupakan definisi dari latihan (Bompa 1999: 394). Dengan kata lain, olahraga yang dilakukan secara rutin dan konsisten disebut latihan. Suharjana (2013: iii) mengatakan bahwa olahraga yang 
teratur adalah olahraga yang dilakukan secara kontinyu satu minggu tiga kali, dengan waktu latihan antara 20-60 menit untuk setiap kali olahraga.

Ada banyak manfaat yang bisa didapatkan dengan melakukan aktivitas olahraga secara rutin. Menurut para ahli, kegiatan melakukan aktivitas olahraga tidak hanya dapat membuat tubuh semakin sehat dan juga bugar, tetapi aktivitas olahraga juga dapat menghindarkan rasa depresi. Ada penelitian yang telah dilakukan dengan keterkaitan dan juga hubungan antara kegiatan aktivitas olahraga dan juga resiko depresi. Penelitian yang dilakukan selama bertahun-tahun tersebut telah dilakukan dengan menggunakan sebuah metode survei dan juga telah mengundang sekitar 50.000 wanita partisipan. Para partisipan ini diperiksa kesehatan untuk bisa mendapatkan sebuah hasil penelitian yang cukup akurat. Hasil survei tersebut telah memperlihatkan bahwa dengan aktivitas olahraga secara rutin yaitu setidaknya selama beberapa tahun akan dapat membantu menurunkan resiko depresi. Bagi yang telah melakukan kegiatan olahraga secara rutin yaitu sekitar 90 menit atau lebih dalam satu hari akan memiliki resiko depresi $20 \%$ lebih kecil dibandingkan dengan mereka yang beraktivitas olahraga hanya 10 menit dalam satu hari.

Dalam penelitian tersebut juga mengatakan bahwa seseorang yang jarang beraktivitas dan hanya mengisi waktu luangnya dengan bersantai atau hanya menonton televisi akan memiliki resiko tinggi mengalami depresi pada hari berikutnya. Menurut para ahli, dengan meninggalkan kebiasaan malas-malasan dengan bergerak aktif dan serta beraktivitas olahraga dapat mempengaruhi mood ke arah yang lebih baik dan dapat meningkatkan endorfin yang bisa membantu mengurangi stress dan depresi. Temuan ini juga menambahkan adanya bukti bahwa kegiatan fisik sangat penting untuk kesehatan otak, ujar Dr. Gillian Mead (seputarfitness.com).

Sadoso Sumosardjuno (1996: 3) mengatakan bahwa olahraga atau latihan dapat memperbesar dan meningkatkan mitokondria. Terdapat $120 \%$ kenaikan pada jumlah mitokondria pada otot vastus lateralis, setelah melakukan latihan selama 28 minggu dengan frekuensi lima kali seminggu, yaitu lari jarak jauh dan senam. Olahraga dapat digolongkan menjadi dua jenis berdasarkan sistem energi yang digunakan. Berdasarkan sistem energi yang digunakan, olahraga dibagi menjadi dua jenis, yaitu aerobik dan anaerobik. Olahraga anaerobik adalah setiap kegiatan fisik atau latihan yang dilakukan dengan intensitas tinggi dalam waktu yang singkat karena berada dalam kondisi tanpa oksigen. Manfaat olahraga anaerobik yaitu: 
a. Membantu meningkatkan kekuatan massa otot serta tulang.

b. Membentuk otot dan tampilan tubuh yang menawan.

c. Melancarkan sirkulasi darah dalam tubuh, meningkatkan vitalitas dan energi.

d. Meningkatkan kecepatan, kekuatan, dan laju metabolisme tubuh.

e. Meningkatkan stamina, terutama untuk atlet olahraga.

\section{METODE PENELITIAN}

Penelitian tentang perbedaan pola tidur antara yang terlatih dan tidak terlatih ini merupakan penelitian ex-post-facto. Ex-post-facto adalah penelitian yang dilakukan untuk meneliti peristiwa yang telah terjadi yang kemudian merunut ke belakang untuk mengetahui faktor-faktor yang dapat menimbulkan kejadian tersebut. Variabel bebas (independent) adalah "tingkat keterlatihan", yaitu yang terlatih (X 1) dan tidak terlatih (X 2). Member senam aerobik The Sahid Rich Yogyakarta Hotel sebagai X 1 dan ibu-ibu komplek Tarakanita sebagai X 2, sedangkan variabel terikat (dependent) yaitu pola tidur (Y).

Populasi dalam penelitian ini yaitu seluruh member senam aerobik dan ibu-ibu komplek Tarakanita. Teknik pengambilan sampel dalam penelitian ini menggunakan teknik purposive sampling. Hal ini dikarenakan tidak semua member senam aerobik di The Sahid Rich Yogyakarta Hotel aktif dalam melakukan latihan, maka dari itu sampel yang dipilih adalah member senam aerobik yang telah rutin melakukan senam, setidaknya tiga kali dalam seminggu dan telah latihan senam di atas dua bulan. Sampel dari ibu-ibu komplek Tarakanita pun juga akan dipilih dari kelompok yang jarang berolahraga. Pertimbangan ini ditujukan agar hasil yang didapatkan akan terlihat secara nyata perbedaan pola tidur yang terlatih dan tidak terlatih.

\section{HASIL PENELITIAN}

\section{Pola Tidur Kelompok Tidak Terlatih}

Dari hasil analisis dengan bantuan program SPSS diperoleh skor terendah 71 dan skor tertinggi 113, dengan mean sebesar 94,000 dan standar deviasi $= \pm 10,112$. Skor mean tersebut berada pada interval kelas 66 s.d. 102 kategori Cukup Baik. Dapat disimpulkan bahwa pola tidur kelompok tidak terlatih dikategorikan cukup baik.

Tabel 2. Frekuensi Skor Pola Tidur Kelompok Tidak Terlatih

\begin{tabular}{|c|c|c|c|c|}
\hline Nilai & Interval Skor & Frekuensi (f) & Presentase (\%) & Kategori \\
\hline 1. & 103 s.d. 140 & 2 & 11,8 & Baik \\
2. & 66 s.d. 102 & 15 & 88,2 & Cukup Baik \\
3. & 28 s.d. 65 & 0 & 0 & Kurang Baik \\
\hline \multicolumn{2}{r|}{ Jumlah } & 17 & 100,0 & \\
\hline
\end{tabular}




\section{Pola Tidur Kelompok Terlatih}

Dari hasil analisis dengan bantuan program SPSS diperoleh skor terendah 90 dan skor tertinggi 118, dengan mean sebesar 104,750 dan deviasi standar $=7,389$. Skor mean tersebut berada pada interval kelas 103 s.d. 140 kategori Baik. Dapat disimpulkan bahwa pola tidur kelompok terlatih dikategorikan baik.

\section{Tabel 3. Frekuensi Skor Pola Tidur Kelompok Terlatih}

\begin{tabular}{|l|l|l|l|l|}
\hline Nilai & Interval Skor & Frekuensi (f) & Presentase (\%) & Kategori \\
\hline 1. & 103 s.d. 140 & 9 & 56,3 & Baik \\
2. & 66 s.d. 102 & 7 & 43,8 & Cukup Baik \\
3. & 28 s.d. 65 & 0 & 0 & Kurang Baik \\
\hline Jumlah & 16 & 100,0 & \\
\hline
\end{tabular}

\section{PEMBAHASAN}

Berdasarkan analisis data terdapat perbedaan yang signifikan antara pola tidur kelompok terlatih dan tidak terlatih. Hasil tersebut ditunjukkan dengan t hitung sebesar 3,468 dan $\mathrm{p}=$ 0,002. Dikarenakan p lebih kecil dari 0,05 atau $5 \%$ maka dapat disimpulkan bahwa ada perbedaan yang signifikan antara pola tidur dari kedua kelompok.. Mean yang diperoleh kelompok tidak terlatih sebesar 94,00 dengan kategori cukup baik, sedangkan mean yang lebih tinggi dimiliki oleh kelompok terlatih sebesar $=104,75$ dengan kategori baik. Dari mean yang didapatkan dari dua kelompok tersebut menunjukkan bahwa skor kelompok terlatih lebih tinggi dari skor kelompok tidak terlatih. Hasil tersebut yang menunjukkan bahwa pola tidur kelompok terlatih lebih baik dari kelompok tidak terlatih. Hal ini tidak lepas dari aktivitas fisik berupa latihan rutin senam aerobik yang dilakukan ibu-ibu member senam aerobik di The Sahid Rich Yogyakarta Hotel. Selain itu tingkat sosial dan ekonomi yang tergolong lebih tinggi mampu menunjang kualitas hidup yang lebih baik sehingga pola tidur member senam aerobik di The Sahid Rich Yogyakarta Hotel menjadi lebih baik.

Hasil penelitian ini membuktikan bahwa orang dengan tingkat keterlatihan yang baik dapat memberikan dampak positif untuk mendapatkan pola tidur yang lebih baik, dengan kata lain orang yang bugar akan memiliki pola tidur yang baik. Hal ini disebabkan kadar endorfin yang meningkat dengan latihan aerobik dapat menyebabkan suasana hati menjadi senang sehingga mempengaruhi pola tidur menjadi lebih baik. Faktor usia juga dapat berpengaruh terhadap kemungkinan gangguan tidur yang terjadi, karena dari data yang diperoleh usia rata- 
rata kelompok tidak terlatih lebih tinggi dari usia rata-rata kelompok terlatih. Orang yang telah terlatih dan memiliki kebugaran yang baik memiliki denyut nadi istirahat yang baik. Penurunan denyut jantung berarti jantung bekerja lebih efisien karena membutuhkan oksigen lebih sedikit. Menurunnya denyut jantung dapat menciptakan tidur yang lebih baik karena akan memberikan rasa rileks.

\section{KESIMPULAN}

Berdasarkan deskripsi data, pengujian hipotesis dan pembahasan yang telah dilakukan dapat disimpulkan bahwa terdapat perbedaan pola tidur antara kelompok yang terlatih dan kelompok yang tidak terlatih, yaitu pola tidur kelompok yang terlatih berolahraga lebih baik dari kelompok yang tidak terlatih berolahraga.

\section{DAFTAR PUSTAKA}

Acandra. (2010). "Makin tua, kebutuhan tidur menurun". travel.kompas.com diunduh pada tanggal 9 Mei 2015 pada pukul 09:00 WIB

Agnes Wahyu Diani. (2014). "Kesulitan tidur pada mahasiswa yang menyusun skripsi”. Jurnal. Surabaya: UIN Surabaya

Beny Atmadja. (2002). “Fisiologi tidur”. Jurnal. Bandung: Fakultas Kedokteran Bandung

Bompa, T.O (1999). Theory and methology of training. Dubuque: Kendal Hunt Ub. Company

Eko Radityo. (2012). “Depresi dan gangguan tidur”. Jurnal. Denpasar: Fakultas Kedokteraan Universitas Udayana

Ferlin Herliati. (2006). "Pengaruh latihan jogging terhadap pola tidur karyawan PT Maesindo Indonesia cabang Bantul”. Skripsi. Yogyakarta: Universitas Negeri Yogyakarta

Koni. (2011). "Senam”. konidki.or.id. diunduh pada tanggal 8 Mei 2015 pada pukul 14:00 WIB

Lusia Kus Anna. (2015). "Kebutuhan tidur berdasarkan usia". health.kompas.com diunduh pada tanggal 9 Mei 2015 pada pukul 08:10 WIB

Lynne Brick. (2001). Bugar dengan senam aerobik. Jakarta: PT Rajagrafindo.

Moses Wong. (2005). Tidur tanpa obat. Jakarta: Bumi Aksara

. (2014). "Manfaat beraktivitas olahraga". seputarfitness.com diunduh pada tanggal 23 Oktober 2015 pada pukul 08:00 WIB.

Prayitno. (2002). "Gangguan pola tidur pada kelompok usia lanjut dan penatalaksanaanya". Jurnal. Jakarta: Fakultas Kedokteraan Universitas Trisakti. 
Rizki Yuniarti. (2012). "Pengaruh senam aerobik dan bersepeda terhadap kesejahteraan psikologis remaja putri”. Skripsi. Yogyakarta: Universitas Negeri Yogyakarta.

Sadoso Sumosardjuno. (1986). Perubahan fisiologis karena latihan fisik. Jakarta: PT Gramedia Pustaka Utama.

Sadoso Sumosardjuno. (1996). Sehat \& bugar. Jakarta: PT Gramedia Pustaka Utama.

Setiyo Purwanto. (2008). "Mengatasi insomnia dengan terapi relaksasi”. Jurnal. Surakarta: Universitas Muhammadiyah Surakarta.

Suryandriyo, Baskoro. (2013). "Pengertian atau arti makna dan definisi olahraga secara umum". ikerenki.com diunduh pada tanggal 23 Oktober 2015 pada pukul 08:00 WIB.

Tracey Kelly. (2005). 50 Rahasia alami tidur yang berkualitas. Jakarta: Erlangga.

Trusna Nurmansyah. (2009) "Hubungan informasi tentang tindakan keperawatan dengan pola tidur pasien dewasa di ruang rawat inap kelas III RSUD kota semarang”. Jurnal. Semarang: Unimu

Uyung Pramudiarja. (2015). "Akibat tidak pernah olahraga". m.detik.com diunduh pada tanggal 9 Mei 2015 pada pukul 10:00 WIB.

Vera Farah. (2010). "28 juta orang indonesia terkena insomnia". m.detik.com diunduh pada tanggal 14 Januari 2015 pada pukul 18:30 WIB.

Woerjati Soekarno. (1996). Teori \& praktek senam dasar. Klaten: PT. Intan Pariwara. 
